\title{
Genomic Databases and the Search of Protein Targets for Protozoan Parasites
}

\author{
Luís Fernando S.M. Timmers ${ }^{1}$, Ivani Pauli ${ }^{1}$, Guy Barros Barcellos ${ }^{1}$, Kelen Beiestorf Rocha ${ }^{1}$, \\ Rafael Andrade Caceres ${ }^{1,2}$, Walter Filgueira de Azevedo Jr. ${ }^{1,2}$ and Milena Botelho Pereira Soares ${ }^{3,4, *}$
}

\author{
${ }^{I}$ Faculdade de Biociências, Laboratório de Bioquímica Estrutural, Pontifícia Universidade Católica do Rio Grande do \\ Sul, Porto Alegre - RS, Brazil, ${ }^{2}$ Programa de Pós-Graduação em Medicina e Ciências da Saúde, Pontifícia Universi- \\ dade Católica do Rio Grande do Sul, Porto Alegre - RS, Brazil; ${ }^{3}$ Centro de Pesquisas Gonçalo Moniz, Fundação \\ Oswaldo Cruz. Rua Waldemar Falcão, 121. Candeal 40296-710 - Salvador, BA - Brazil; ${ }^{4}$ Hospital São Rafael. Av. São \\ Rafael, 2152. São Marcos 41253-190 - Salvador, BA, Brazil
}

\begin{abstract}
The development of databases devoted to biological information opened the possibility to integrate, query and analyze biological data obtained from several sources that otherwise would be scattered through the web. Several issues arise in the handling of biological information, mainly due to the diversity of biological subject matter and the complexity of biological approaches towards phenomena of the living world. The integration of genomic data, three-dimensional structures of proteins, biological activity, and drugs availability allows a system approach to the study of the biology. Here we review the current status of these research efforts to develop genomic databases for protozoan parasites, such as the apicomplexan parasites, Trypanosoma cruzi and Leishmania spp. These databases may help in the discovery and development of new drugs against parasite-mediated diseases.
\end{abstract}

Key Words: Databases, genomes, protozoan parasites, apicomplexa, Cryptosporidium parvum, Plasmodium falciparum, Leishmania spp., Toxoplasma gondii, Trypanosoma cruzi.

\section{INTRODUCTION}

Protozoan parasites compose a very diverse group of unicellular organisms of the kingdom Protista, some of which have evolved to parasitize humans. The study of parasite biology has attracted attention not only because they are fascinating organisms, but also due to the need of finding tools and developing therapeutic strategies and vaccines, still in great need due to the remarkable social and economic burden they cause on human societies, especially in tropical and subtropical regions of the world [1]. To understand how pathogens infect and survive within their hosts is crucial to identify potential therapeutic targets for parasite-mediated diseases.

Drugs can be designed to target and inhibit the function of proteins involved in specific pathways, e.g. shikimate pathway [2-14], purine pathway [15-30], or specific protein targets such as Cyclin-Dependent Kinases [31]. Several metabolic pathways of pivotal importance for the parasites have been proven drug targets for many years. One of the most studied enzymes is Purine Nucleoside Phosphorylase (PNP; EC 2.4.2.1), which participates in de novo synthesis, salvage and interconversion of purines and pyrimidines [32]. The purine salvage pathway is the only possible way for apicomplexan parasites to obtain the building blocks for RNA and DNA synthesis, which makes PNP from these parasites

*Address correspondence to this author at the Centro de Pesquisas Gonçalo Moniz, Fundação Oswaldo Cruz. Rua Waldemar Falcão, 121. Candeal 40296-710 - Salvador, BA - Brazil; E-mail: milena@bahia.fiocruz.br an attractive target for drug development against diseases, such as malaria [32].

PNP catalyzes the reversible phosphorolysis of nucleosides and deoxynucleosides, generating ribose 1-phosphate and the purine base, which is an important step of purine catabolism pathway. PNP from Plasmodium falciparum had its crystallographic structure elucidated, which opened the possibility to use this structural information to guide virtual screening initiatives.

The structure of PNP from $P$. falciparum (PfPNP) in complex with 3,4-Dihydroxy-2-[(methylsulfanyl)methyl]-5(4-oxo-4,5-dihydro-3H-pyrrolo[3,2-D] pyrimidin-7-YL) pyrrolidinium (MTI) is shown in Fig. (1A) and Fig. (1B) presents the active binding site of the PfPNP:MTI.

Analysis of the available genomic databases for Cryptosporidium parvum, Leishmania braziliensis, Toxoplasma gondii, Trypanosoma cruzi indicates the presence of this enzyme in other genomes, therefore molecular modeling initiatives may generate reliable model for these PNPs, and use this model for structure-based virtual screening initiatives.

The need to understand protein networks has become evident in the so-called "post-genomic Era", due to the explosion in biological and chemical knowledge resulting of genomes sequencing. There is simply too much data (images, models, three-dimensional structures and sequences) available from too many sources [2]. This information may be used to identify potential protein targets in a sequenced 

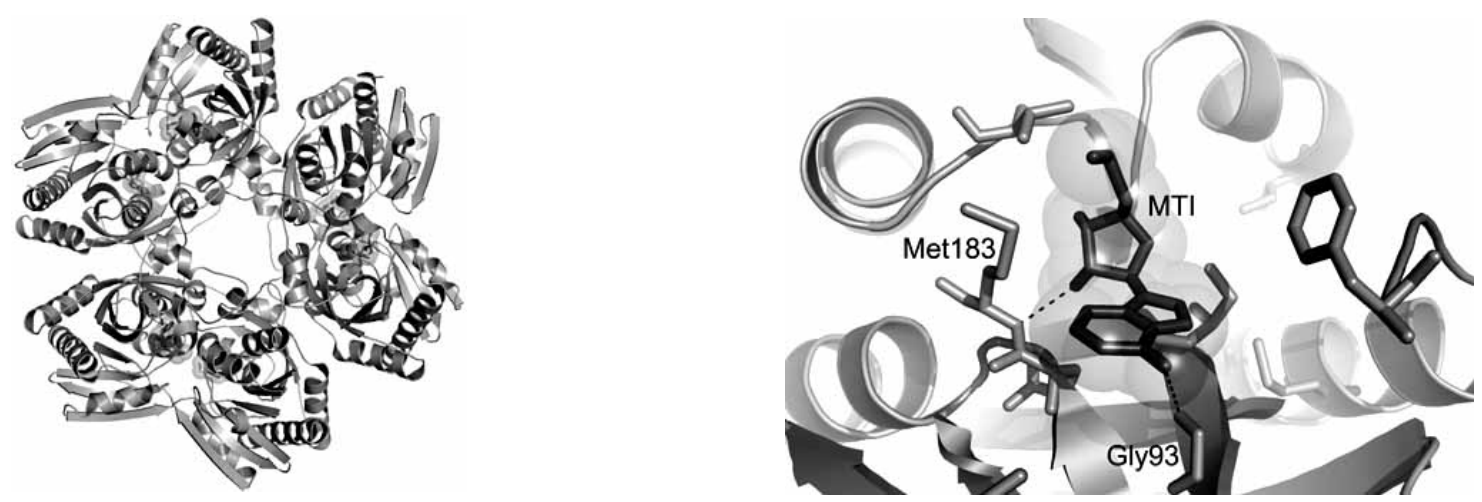

Fig. (1). A Binary complex involving purine nucleoside phosphorylase from Plasmodium falciparum (PfPNP) and MTI (PDB access code: 1Q1G) [90]. B Active-binding site of the PfPNP in complex with MTI.

genome, and a considerable effort has been dedicated to genome sequencing projects, including those of parasites.

Researchers interested on protozoan parasites have benefited from the bioinformatics resources provided by several online genome databases available, such as CryptoDB [33], PlasmoDB [34]. ToxoDB [35], GiardiaDB, and TrichDB [36]. In addition, because of the phylogenetic relationship of human pathogens (e.g. Cryptosporidium, Plasmodium, Giardia, Trichomonas, and Toxoplasma, which belong to the phylum Apicomplexa), comparative genomic and proteomic studies across related species can accelerate the discovery of therapeutic targets, in addition to increase our understanding of parasite biology and enhance other areas of biological research [37].

To aid the molecular design for drug discovery in parasitic diseases, several searchable databases were created. In this review we examine recent developments related to the genomic databases for protozoan parasites, especially focusing on Cryptosporidium parvum, Plasmodium falciparum, Leishmania spp, Toxoplasma gondii, and Trypanosoma cruzi.

\section{Eukaryotic Pathogens Database Resources (EuPathDB)}

The Eukatiotic Pathogens Database Resources (EuPathDB) is one of the eight databases available at Bioinformatics Resources Center (BRC) Central, a database repository sponsored by the National Institute of Allergy and Infectious Diseases (NIAID) providing web-based resources to the scientific community conducting basic and applied research on organisms considered potential agents of biowarfare or bioterrorism or causing emerging or re-emerging diseases. In addition to EuPathDB, BRD Central (http://www. brc-central.org) currently includes the following databases: the Biodefense and Public Health Database (BioHealthBase), the Enteropathogen Resource Integration Center (ERIC), the National Microbial Pathogen Data Resource (NMPDR), the PATHEMA, the PathoSystems Resource Integration Center (PATRIC), the Viral Bioinformatics Resource Center (VBRC), and the VectorBase.
Starting with functional genomics databases for apicomplexan parasites Toxoplasma, Cryptosporidium, Plasmodium and, more recently, Giardia and Trichomonas [Aurrecoechea 2008], EuPathDB (http://eupathdb.org) is gradually including databases for other eukaryotic pathogens, such as TrypDB (comprising databases for kinetoplastid parasites Leishmania sp, Trypanosoma cruzi and T. brucei), announced to be released in January 2009. Several resources are available at EuPathDB, including SRT (Sequence Retrieval), metabolic pathways, BLAST, and metabolic pathway maps.

\section{Toxoplasma gondii Database (ToxoDB)}

Toxoplasma gondii is an opportunistic apicomplexan pathogen that causes a spectrum of diseases um humans which mainly afflicts immunocompromised individuals and congenitally infected children [38,39]. Although usually asymptomatic in healthy individuals, infection by $T$. gondii may cause acute ocular disease, congenital birth defects and encephalitis in immunosuppressed individuals [33,40,41].

A genome and functional genomic database for Toxoplasma gondii, ToxoDB (http://ToxoDB.org), was first released in 2001. Its current version (release 5.0) contains fully sequenced and annotated genomes of three strains of $T$. gondii: GT1 (Type I), ME49 (Type II) and VEG (Type III) [33]. Sequence information is integrated with various other genomic-scale data, including community annotation, ESTs, gene expression, and proteomics data [33]. It was recently reported the first multi-platform global proteome analysis of Toxoplasma tachyzoites, resulting in the identification of nearly one-third of the entire predicted proteome of $T$. gondii, which represents a significant advance in our understanding of protein expression in this important pathogen [42].

\section{Cryptosporidium Database (CryptoDB)}

Cryptosporidium parvum is an apicomplexan coccidian parasite causative of cryptosporidiosis, and an important AIDS-associated pathogen. Infection by this parasite causes an acute gastrointestinal disease that manifests as self- 
limiting diarrhea in normal individuals, but can lead to death in immunocompromised individuals [43-45].

CryptoDB (http://CryptoDB.org) is a database which integrates whole genome sequence and annotation with EST and genome survey sequence data for Cryptosporidium. In addition, supplemental bioinformatics analyses and datamining tools (via BLAST, keyword searches of pre-computed BLASTX results and user-defined or PROSITE motif pattern searches) are available at CryptoDB [44]. Its most recent version (release 3.7 of February 2008) includes data on Cryptosporidium hominis (strain TU502), C. parvum (strain IOWA), and C. muris.

\section{Plasmodium Database (PlasmoDB)}

Malaria is one of the principal causes of mortality in Africa, Southeast Asia, and Latin America [46]. There is a worldwide increasing concern about malaria, not only because of high morbidity and mortality, but also because of the progressive increase of its prevalence in tropical areas $[47,48]$. Currently the World Health Organization estimates that malaria infection causes 300 million cases of acute illnesses and at least one million deaths annually, primarily of children under 5 years of age [46]. Plasmodium falciparum is the causative agent of the most virulent form of human malaria [47]. Malaria parasite resistance to therapeutic drugs has increased significantly during the past two decades [4850].

Protein structure has previously been used to elucidate the mechanism of resistance in $P$. falciparum $[51,52]$. To illustrate, a search performed in December 2008 in the Protein Data Bank (PDB) [53] using "falciparum" as keyword retrieved 210 structures. Once sequences with more than $90 \%$ sequence identity were removed, 103 structures remained [53]. Therefore, comparative genomic analyses of related pathogens (such as $P$. vivax) will facilitate understanding of the common mechanisms used by these pathogens, as well as their differences [54].

PlasmoDB (http://plasmodb.org) is a database containing Plasmodium genomic sequences and gene annotations first released in June 2000 [55]. In its most recent edition (release 5.5 of September 15), PlasmoDB includes genomic, proteomic, and several additional data for different species of Plasmodium, including P. falciparum (strain 3D7), P. vivax, $P$. berghei, $P$. yoelii, $P$. chabaudi, and $P$. knowlesi. New datasets in PlasmoDB provide predictions and clues about how the component parts work together. Experimental evidence for interacting proteins is provided with a yeast twohybrid dataset for $P$. falciparum $[56,57]$. Computational predictions for functional interactions in $P$. falciparum are also provided based on co-evolution and co-expression of genes [55-58].

As an example, a search on PlasmoDB using the word "chorismate" returned thirteen genes (in December 2008), with information about gene identification, organism, genomic location, and product description. By clicking on one of the genes, the user has access to information about sequence alignment, metabolic pathway, paralogs and ingenera orthologs. This database furnishes information that can be directly used to help identifying new protein targets for development of antimalarial drugs.

\section{Leishmania Genome Network}

Leishmania is a kinetoplastid protozoan parasite belonging to the family Trypanosomatidae. The different species of Leishmania are responsible for a wide spectrum of human diseases, occurring mostly in the tropics and subtropics [59]. Leishmaniases cause the killing of thousands and debilitate millions of people yearly. With 2 million new cases reported annually and 350 million people at risk, infection by Leishmania spp. represents an important global health problem for which there is no vaccine and few effective drugs available [60]. Infection by Leishmania can cause diseases with manifestations ranging from cutaneous and mucocutaneous lesions to visceral infection affecting the haemopoetic organs, depending of the parasite species as well as the host's immune response.

Several potential protein targets for drug development in Leishmania are under preliminary studies, such as enzymes from the purine and pyrimidine pathways [61]. In addition, the understanding of the cell cycle of these parasites in order to identify important structural and functional differences between parasite and mammalian cell cycle control machineries might be utilized for rational drug design. Potential targets include protein kinases from the cyclin-dependent kinase family, cAMP-dependent kinase and mitogenactivated protein kinase families [62-65].

GeneDB (http://www.genedb.org) is a genome database for prokariotic and eukariotic organisms created as a result of efforts done in gene sequencing of several organisms. It contains data from finished and ongoing genome and EST projects with curated annotation generated by the Pathogen Sequencing Unit at the Wellcome Trust Sanger Institute and other collaborating sequencing centers that are made freely and immediately available [66].

The Leishmania Genome Network (LGN) is part of the international parasite genome projects coordinated by the World Health Organization Special Program for Research and Training in Tropical Diseases (TDR), and includes data on Leishmania major (MHOM/IL/80/Friedlin) L. infantum (clone JPCM5 MCAN/ES/98/LLM-877), L. braziliensis (clone M2904 MHOM/BR/75M2904) and L. mexicana (MHOM/GT/2001/U1103).

Three Leishmania databases are currently available at GeneDB, the L. major GeneDB (www.genedb.org/genedb/ leish), the L. braziliensis GeneDB (www.genedb.org/genedb/ lbraziliensis) and the L. infantum GeneDB (www.genedb. org/genedb/linfantum). These databases provide access to DNA and protein sequences of protein coding genes with the ability of sending sequences straight to the associated BLAST servers, as well as to other resources, such as predicted peptide properties (including signal peptide and transmembrane predictions), similarity information (EMBL, SWISS-PROT including annotation), gene ontology (GO) annotation, summary of up-to-date protein domain and motif searches (InterPro, Pfam, PRINSTS, PROSITE, BLOCKS, SMART), literature links, and SWISS-PROT annotation [66]. 


\section{Trypanosoma cruzi Database (TcruziDB)}

American trypanosomiasis, also known as Chagas' disease, caused by infection with the kinetoplastid protozoan Trypanosoma cruzi, is a serious health problem in Latin America, where it affects 16 to 18 million people [67]. $T$. cruzi is capable of infecting different cell types in the mammalian host. It has, frequently, a preference to invade muscle cells, including cardiomyocytes. In the acute phase of infection, parasites are easily found replicating in different tissues and organs, as well as circulating in the blood. As the adaptive immune responses are stimulated, the high tissue parasitism is controlled, but never eradicated [68].

The parasite persistence causes, in about $30 \%$ of the infected individuals, the development of chronic symptomatic forms, mainly the chronic chagasic cardiomyopathy [68, 69]. Being one of the leading causes of heart failure in Latin American countries, Chagas' disease remains today with benznidazole as the only World Health Organizationrecommended drug for its treatment, but its high toxicity and low efficacy, especially during the chronic phase of infection, encourage the search for new drugs [69]. Thus, there is a great need for development of new chemotherapeutic agents for Chagas' disease treatment.

The help the scientific community to access the $T$. cruzi genome sequencing data, it was created in 2003 an integrated database, TcruziDB (http://TcruziDB.org). TcruziDB provides access to the genome sequence (CL-Brener strain) and to a whole-genome proteomic analysis covering the four main life cycle stages of the parasite, among other resources. The combination of an annotated genome and a relational architecture has facilitated the integration of genomic data with expression data (and proteomic EST) and allowed the construction of automated analysis pipelines. TcruziDB accepted, and will continue to accept, the deposition of functional genomics and genomic data, contributing to the research community, which may help to identify new $T$. cruzi protein targets suitable for drug discovery and development [70].

\section{CONCLUDING REMARKS}

There is still a great need for drug development against parasitic diseases, which affect hundreds of millions of people worldwide and result in a significant mortality and devastating social and economic consequences in many developing countries [71]. Because they mainly affect poor people in developing regions of the world they are not considered as viable target markets for the pharmaceutical industry. An explosion of data and analysis from parasite genome projects have occurred within the past few years. Although several potential parasitic targets have been proposed as the result of comparative genome searches and microarray analysis, their validation as useful targets will require the support of basic research on parasite biology.

Metabolic and structural differences between infective organisms and their hosts may provide characterization of molecular targets for the development of selective inhibitors. These differences are of great importance in order to develop rational approaches to anti-parasite chemotherapy [32].
The genomic data allied to molecular biology and bioinformatics tools provides knowledge to identify molecular targets providing subsides to the principles of the rational drug design considering the toxicity and selectivity. Many applications of bioinformatics tools to the development of antiparasitic drugs have been recently reviewed [73-89]. Thus, the development of parasite databases allows full integration of web resources [56]. Integration of structure-based virtual screening methodologies with the public databases, as the ones discussed in this review, are essential to identify a new generation of anti-parasite drugs.

\section{ACKNOWLEDGMENTS}

This work was supported by grants from Institutos do Milênio, FINEP, CNPq and Instituto Nacional de Ciência e Tecnologia do Conselho Nacional de Desenvolvimento Científico e Tecnológico-Ministério de Ciência e Tecnologia (INCT-Tuberculose, CNPq-MCT, Brazil). IP, LFSMT, KBR, and $\mathrm{RAC}$ would like to thank $\mathrm{CNPq}$ for the fellowships. MBPS and WFA are senior researchers for CNPq (Brazil).

\section{ABBREVIATIONS}

\begin{tabular}{|c|c|c|}
\hline piDB & $=$ & $\begin{array}{l}\text { Apicomplexan Bioinformatics Reso } \\
\text { Center }\end{array}$ \\
\hline CryptoDB & $=$ & Cryptosporidium database \\
\hline MTI & $=$ & $\begin{array}{l}\text { 3,4-Dihydroxy-2-[(methylsulfanyl)m } \\
\text { 5-(4-oxo-4,5-dihydro-3Hpyrrolo[3,2 } \\
\text { D]pyrimidin-7-YL)pyrrolidinium }\end{array}$ \\
\hline PlasmoDB & $=$ & Plasmodium database \\
\hline PNP & $=$ & Purine Nucleoside Phosphorylase \\
\hline TcruziDB & $=$ & Trypanosoma cruzi database \\
\hline TDR & $=$ & $\begin{array}{l}\text { Special Programme for Research \& } \\
\text { Training in Tropical Diseases }\end{array}$ \\
\hline ToxoDB & $=$ & Toxoplasma gondii database \\
\hline ST & - & Expressed Sequence Tag \\
\hline
\end{tabular}

\section{REFERENCES}

[1] Cooper, R.A. and Carucci, D.J. (2004) Curr. Drug Targets Infect. Disord., 4(1), 41-51.

[2] Pereira, J.H.; Vasconcelos, I.B.; Oliveira, J.S.; Caceres, R.A.; De Azevedo Jr., W.F.; Basso, L.A. and Santos, D.S. (2007) Curr. Drug Targets, 8(3), 459-468.

[3] Pauli, I.; Caceres, R.A. and De Azevedo Jr., W.F. (2008) Bioorg. Med. Chem., 16(17), 8098-8108.

[4] Arcuri, H.A.; Canduri, F.; Pereira, J.H.; da Silveira, N.J.F.; Câmara Jr., J.C.; de Oliveira, J.S.; Basso, L.A.; Palma, M.S.; Santos, D.S. and De Azevedo Jr., W.F. (2004) Biochem. Biophys. Res. Commun., 320(3), 979-991.

[5] Pereira, J.H.; Oliveira, J.S.; Canduri, F.; Dias, M.V.B.; Palma, M.S.; Basso, L.A.; Santos, D.S. and De Azevedo, W.F. (2004) Acta.Crystallogr. Sect. D.-Biol. Crystallogr., 60, 2310-2319.

[6] Borges, J.C.; Pereira, J.H.; Vasconcelos, I.B.; dos Santos, G.C.; Olivieri, J.R.; Ramos, C.H.I.; Palma, M.S.; Basso, L.A.; Santos, D.S. and De Azevedo Jr., W.F. (2006) Arch. Biochem. Biophys., 452(2), 156-164.

[7] Arcuri, H.A.; Borges, J.C.; Fonseca, I.O.; Pereira, J.H.; Neto, J.R.; Basso, L.A.; Santos, D.S. and De Azevedo, W.F. Jr. (2008) Proteins, 72(2), 720-730.

[8] Dias, M.V.; Borges, J.C.; Ely, F.; Pereira, J.H.; Canduri, F.; Ramos, C.H.; Frazzon, J.; Palma, M.S.; Basso, L.A.; Santos, D.S. and De Azevedo, W.F. Jr. (2006) J. Struct. Biol., 154(2), 130-143. 
[9] Dias, M.V.B.; Faim, L.M.; Vasconcelos, I.B.; Oliveira, J.S.; Basso, L.A.; Santos, D.S. and De Azevedo Jr., W.F. (2007) Acta Crystallograph. Sect. F Struct. Biol. Cryst. Commun., 63(1), 1-6.

[10] Marques, M.R.; Pereira, J.H.; Oliveira, J.S.; Basso, L.A.; Santos, D.S.; De Azevedo Jr., W.F. and Palma, M.S. (2007) Curr. Drug Targets, 8(3), 445-457.

[11] Dias, M.V.B.; Ely, F.; Palma, M.S.; De Azevedo Jr., W.F.; Basso, L.A. and Santos, D.S. (2007) Curr. Drug Targets, 8(3), 437-444.

[12] Marques, M.R.; Vaso, A.; Neto, J.R.; Fossey, M.A.; Oliveira, J.S.; Basso, L.A.; dos Santos, D.S.; De Azevedo Jr., W.F. and Palma, M.S. (2008) Biochemistry, 47(28), 7509-7522.

[13] Pereira, J.H.; Canduri, F.; de Oliveira, J.S.; Silveira, N.J.F.; Basso, L.A.; Palma, M.S. De Azevedo, W.F. and Santos, D.S. (2003) Biochem. Biophys. Res. Commun., 312(3), 608-614.

[14] De Azevedo Jr., W.F.; de Oliveira, J.S.; Basso, L.A.; Palma, M.S.; Pereira, J.H.; Canduri, F. and Santos, D.M. (2002) Biochem. Biophys. Res. Commun., 295(1), 142-148.

[15] Caceres, R.A.; Saraiva Timmers, L.F.; Dias, R.; Basso, L.A.; Santos, D.S. and De Azevedo Jr., W.F. (2008) Bioorg Med Chem., 16(9), 4984-4993.

[16] De Azevedo Jr., W.F.; Canduri, F.; Dos Santos, D.M.; Pereira, J.H.; Dias, M.V.B.; Silva, R.G.; Mendes, M.A.; Basso, L.A.; Palma, M.S. and Santos, D.S. (2003) Biochem. Biophys. Res. Commun., 309(4), 917-922.

[17] Canduri, F.; Fadel, V.; Dias, M.V.B.; Basso, L.A.; Palma, M.S.; Santos, D.S. and De Azevedo, W.F.Jr. (2005) Biochem. Biophys. Res. Commun., 326(3), 335-338.

[18] Canduri, F.; Silva, R.G.; dos Santos, D.M.; Palma, M.S.; Basso, L.A.; Santos, D.S. and De Azevedo, W.F.Jr. (2005) Acta Crystallogr. D Biol. Crystallogr., 61(7), 856-862.

[19] Nolasco, D.O.; Canduri, F.; Pereira, J.H.; Cortinoz, J.R.; Palma, M.S.; Oliveira, J.S.; Basso, L.A.; De Azevedo, W.F.Jr. and Santos, D.S. (2004) Biochem. Biophys. Res. Commun., 324(2), 789-794.

[20] Canduri, F.; Fadel, V.; Basso, L.A.; Palma, M.S.; Santos, D.S. and De Azevedo, W.F.Jr. (2005) Biochem. Biophys. Res. Commun., 327(3), 646-649.

[21] Silva, R.G.; Pereira, J.H.; Canduri, F.; De Azevedo, W.F.Jr.; Basso, L.A. and Santos, D.S. (2005) Arch. Biochem. Biophys., 442(1), 4958 .

[22] Timmers, L.F.S.M.; Caceres, R.A.; Vivan, A.L.; Gava, L.M.; Dias, R.; Ducati, R.G.; Basso, L.A.; Santos, D.S. and De Azevedo, W.F.Jr. (2008) Arch. Biochem. Biophys., 479, 28-38.

[23] Da Silveira, N.J.F.; Uchoa, H.B.; Canduri, F.; Pereira, J.H.; Camara, Jr.; Basso, L.A.; Palma, M.S.; Santos, D.S. and De Azevedo Jr., W.F. (2004) Biochem. Biophys. Res. Commun., 322(4), 100-104.

[24] Canduri, F.; dos Santos, D.M.; Silva, R.G.; Mendes, M.A.; Basso, L.A.; Palma, M.S.; De Azevedo, W.F. and Santos, D.S. (2004) Biochem. Biophys. Res. Commun., 313(4), 907-914.

[25] De Azevedo Jr., W.F.; Canduri, F.; dos Santos, D.M.; Pereira, J.H.; Silva, R.G.; Mendes, M.A.; Basso, L.A.; Palma, M.S. and Santos, D.S. (2003) Biochem. Biophys. Res. Commun., 312(3), 767-772.

[26] De Azevedo Jr., W.F.; Santos, G.C.; Santos, D.M.; Dos Santos, D.M.; Olivieri, J.R.; Canduri, F.; Silva, R.G.; Basso, L.A.; Renard, G.; Fonseca, I.O.; Mendes, M.A.; Palma, M.S. and Santos, D.S. (2003) Biochem. Biophys. Res. Commun., 309(4), 923-928.

[27] Santos, D.M.; Canduri, F.; Pereira, J.H.; Dias, M.V.B.; Silva, R.G.; Mendes, M.A.; Palma, M.S.; Basso, L.A.; De Azevedo Jr., W.F. and Santos, D.S. (2003) Biochem. Biophys. Res. Commun., 308(3), 553-559.

[28] De Azevedo Jr., W.F.; Canduri, F.; Santos, D.M.; Silva, R.G.; Oliveira, J.S.; Carvalho, L.P.S.; Basso, L.A.; Mendes, M.A.; Palma, M.S. and Santos, D.S. (2003) Biochem. Biophys. Res. Commun., 308(3), 545-552.

[29] Timmers, L.F.; Caceres, R.A.; Basso, L.A.; Santos, D.S. and De Azevedo, W.F.Jr. (2008) Protein Pept. Lett., 15(8), 843-849.

[30] Pauli, I.; Timmers, L.F.S.M.; Caceres, R.A.; Basso, L.A.; Santos, D.S. and De Azevedo, W.F.Jr. (2009) J. Mol. Model., (In Press).

[31] Canduri, F.; Perez, P.C.; Caceres, R.A. and De Azevedo, W.F.Jr. (2008) Med. Chem., 4(3), 210-218.

[32] Datta, A.K.; Datta, R. and Sen, B. (2008) Adv. Exp. Med. Biol., 625, 116-132.

[33] Heiges, M.; Wang, H.; Robinson, E.; Aurrecoechea, C.; Gao, X.; Kaluskar, N.; Rhodes, P.; Wang, S.; He, C.Z.; Su, Y.; Miller, J.;
Kraemer, E. and Kissinger, J.C. (2006) Nucleic Acids Res., 34, D419-D422.

[34] Bahl, A.; Brunk, B.; Crabtree, J.; Fraunholz, M.J.; Gajria, B.; Grant, G.R.; Ginsburg, H.; Gupta, D.; Kissinger, J.C.; Labo, P.; Li, L.; Mailman, M.D.; Milgram, A.J.; Pearson, D.S.; Roos, D.S.; Schug, J.; Stoeckert, C.J. Jr. and Whetzel, P. (2003) Nucleic Acids Res. 31, 212-215.

[35] Gajria, B.; Bahl, A.; Brestelli, J.; Dommer, J.; Fischer, S.; Gao, X.; Heiges, M.; Iodice, J.; Kissinger, J.C.; Mackey, A.J.; Pinney, D.F.; Roos, D.S.; Stoeckert Jr, C.J.; Wang, H. and Brunk, B.P. (2007) Nucleic Acids Res., 36, D553-D556.

[36] Aurrecoechea, C.; Brestelli, J.; Brunk, B.P.; Carlton, J.M.; Dommer, J.; Fischer, S.; Gajria, B.; Gao, X.; Gingle, A.; et al. (2009) Nucleic Acids Res., 37, D526 - D530.

[37] Aurrecoechea, C.; Heiges, M.; Wang, H.; Wang, Z.; Fischer, F.; Rhodes, P.; Miller, J.; Kraemer, E.; Stoeckert Jr., C.J.; Roos, D.S. and Kissinger J.C. (2007) Nucleic Acids Res., 35, 427-430.

[38] Bowie, W.R.; King, A.S.; Werker, D.H.; Isaac-Renton, J.L.; Bell, A.; Eng, S.B. and Marion, S.A. (1997) Lancet, 350, 173-177.

[39] Kim, K. and Weiss, L.M. (2004) Int. J. Parasitol., 34, 423-432.

[40] Luft, B.J. and Remington, J.S. (1992) Clin. Infect. Dis., 15, 211 222.

[41] Remington, J.S. and Desmonts, G. Toxoplasmosis (1989) Remington, J.S. and Klein, J.O., Ed., Philadelphia.

[42] Xia, D.; Sanderson, S.J.; Jones, A.R.; Prieto, J.H.; Yates, J.R.; Bromley, E.; Tomley, F.M.; Lal, K.; Sinden, R.E.; Brunk, B.P.; Roos D.S. and Wastling, J.M. (2008) Genome Biology, 9(7), 1-18.

[43] Dubey, J.P.; Speer, C.A. and Fayer, R. (1990) Cryptosporidiosis of Man and Animal, CRC Press, Inc., Boca Raton, FL.

[44] Peterson,C. (1992) Clin. Infect. Dis., 15, 903-909.

[45] Puiu, D.; Enomoto, S., Buck, G.A.; Abrahamsen, M.S. and Kissinger, J.C. (2004) Nucleic Acids Res., 32, D329-D331.

[46] World Health Organization (2007) Malaria, Fact Sheet No. 94, Geneva, Switzerland.

[47] Breman, J.G. (2001) Am. J. Trop. Med. Hygiene, 64, 1-11

[48] Phillips, R.S. (2001) Clin. Microbiol. Rev., 14, 208-226.

[49] Brooks, D.R.; Wang, P.; Read, M.; Watkins, W.M.; Sims, P.F. and Hyde, J.E. (1994) Eur. J. Biochem., 224, 397-405.

[50] Peterson, D.S.; Walliker, D. and Wellems, T.E. (1988) Proc. Natl. Acad. Sci. U S A, 85, 9114-9118

[51] de Beer, T.A.; Louw, A.I. and Joubert, F. (2006) Bioorg. Med. Chem., 14, 4433-4443.

[52] Yuthavong, Y.; Yuvaniyama. J.; Chitnumsub, P.; Vanichtanankul, J.; Chusacultanachai, S.; Tarnchompoo, B.; Vilaivan, T. and Kamchonwongpaisan, S. (2005) Parasitology, 130, 249-259.

[53] Bernstein, F.C.; Koetzle, T.F.; Williams, G.J.; Meyer, E.F.Jr.; Brice, M.D.; Rodgers, J.R.; Kennard, O.; Shimanouchi, T. and Tasumi, M. (1977) J Mol Biol., 112(3), 535-542.

[54] Joubert, Y. and Joubert, F. (2008) Malaria J., 7, 90.

[55] Stoeckert, Jr., C.J.; Fischer, F.; Kissinger, J.C.; Aurrecoechea, C.; Gajria, B. and Roos, D.S. (2006) Trends Parasitol., 22(12), 543546.

[56] Aurrecoechea, C.; Brestelli, J.; Brunk, B.P.; Dommer, J.; Fischer, S.; Gajria, B.; Gao, X.; Gingle, A.; Grant, G.; Harb, O.S.; Heiges, M.; Innamorato, F.; Iodice, J.; Kissinger, J.C.; Kraemer, E.; Li, W.; Miller, J.A.; Nayak, V.; Pennington, C.; Pinney, D.F.; Roos, D.S.; Ross, C.; Stoeckert, C.J. Jr.; Treatman, C. and Wang, H. (2009) Nucleic Acids Res., 37(Database issue), D539-543.

[57] LaCount, D.J.; Vignali, M.; Chettier, R.; Phansalkar, A.; Bell, R.; Hesselberth, J.R.; Schoenfeld, L.W.; Ota, I.; Sahasrabudhe, S.; Kurschner, C.; Fields, S. and Hughes, R.E. (2005) Nature, 438, 103-107.

[58] Date, S.V. and Stoeckert, C.J., Jr (2006) Genome Res., 16, 542 549.

[59] Croft, S.L.; Sundar, S. and Fairlamb, A.H. (2006) Clin. Microbiol. Rev., 19, 111-126.

[60] http://www.who.int/tdr/diseases/leish/diseaseinfo.htm

[61] Silva, R.G.; Nunes, J.E.; Canduri, F.; Borges, J.C.; Gava, L.M.; Moreno, F.B.; Basso, L.A. and Santos, D.S. (2007) Curr. Drug Targets, 8(3), 413-422.

[62] Hammarton, T.C.; Mottram, J.C. and Doerig, C. (2003) Prog. Cell Cycle Res., 5, 91-101.

[63] Doerig, C. (2004) Biochimica et Biophysica Acta, 1697, 155-168.

[64] Canduri, F.; Perez, P.C.; Caceres, R.A. and de Azevedo, W.F. Jr. (2007) Curr. Drug Targets, 8(3), 389-398. 
[65] Manhani, K.K.; Arcuri, H.A.; da Silveira, N.J.; Uchôa, H.B.; de Azevedo, W.F. Jr. and Canduri, F. (2005) J. Mol. Model., 12(1), $42-48$.

[66] Hertz-Fowler, C.; Peacock, C.S.; Wood, V.; Aslett, M.; Kerhornou, A.; Mooney, P.; Tivey, A.; Berriman, M.; Hall, N.; Rutherford, K.; Parkhill, J.; Ivens, A.C.; Rajandream, M.A. and Barrell, B. (2004) Nucleic Acids Res., 32, 339-343.

[67] World Health Organization. (1995) Chagas' disease: important advances in elimination of transmission in four countries in Latin America. W. H. O. Press Office Feature no. 183. World Health Organization, Geneva, Switzerland.

[68] Soares, M.B.; Pontes-De-Carvalho, L. and Ribeiro-Dos-Santos, R. (2001) An Acad Bras Cienc., 73(4), 547-559.

[69] Garcia, S.; Ramos, C.O.; Senra, J.F.; Vilas-Boas, F.; Rodrigues, M.M.; Campos-de-Carvalho, A.C.; Ribeiro-Dos-Santos, R. and Soares, M.B. (2005) Antimicrob. Agents Chemother., 49(4), 15211528 .

[70] Aguero, F.; Zheng, W.; Weatherly, D. B.; Mendes, P. and Kissinger, J. C. (2006) Nucleic Acids Res., 1(34), D428-D431.

[71] Renslo, A.R. and McKerrow, J.H. (2006) Nat. Chem. Biol., 2, 701710.

[72] De Azevedo Jr., W.F. (2008) Curr. Drug Targets, 9(12), 10301030.

[73] De Azevedo Jr., W.F. and Dias, R. (2008) Curr. Drug Targets, 9(12), 1031-1039.

[74] Canduri, F. and De Azevedo Jr., W.F. (2008) Curr. Drug Targets, 9(12), 1048-1053.

[75] Dias, R.; Timmers, L.F.S.M.; Caceres, R.A. and De Azevedo Jr., W.F. (2008) Curr. Drug Targets, 9(12), 1062-1070.
[76] Caceres, R.A.; Pauli, I.; Timmers, L.F.S.M. and De Azevedo Jr., W.F. (2008) Curr. Drug Targets, 9(12), 1077-1083.

[77] De Amorim, H.L.N.; Caceres, R.A. and Netz, P.A. (2008) Curr Drug Targets, 9(12), 1100-1105.

[78] Pauli, I.; Timmers, L.F.S.M.; Caceres, R.A.; Soares, M.B.P. and De Azevedo Jr., W.F. (2008) Curr. Drug Targets, 9(12), 1054-1061.

[79] De Azevedo Jr., W.F. and Dias, R. (2008) Curr. Drug Targets, 9(12), 1071-1076.

[80] Dias, R. and De Azevedo Jr., W.F. (2008) Curr. Drug Targets, 9(12), 1040-1047.

[81] Timmers, L.F.S.M.; Pauli, I.; Caceres, R.A. and De Azevedo Jr., W.F. (2008) Curr. Drug Targets, 9(12), 1092-1099.

[82] Gobert, G.N. and Jones, M.K. (2008) Curr. Drug Targets, 9(11), 922-930.

[83] Ehrenkaufer, G.M. and Singh, U. (2008) Curr. Drug Targets, 9(11), 931-937.

[84] Kumari, S.; Kumar, A.; Samant, M.; Singh, N. and Dube, A. (2008) Curr. Drug Targets, 9(11), 938-947.

[85] Fleige, T. and Soldati-Favre, D. (2008) Curr. Drug Targets, 9(11), 948-956.

[86] Chauhan, S.C.; Padmanabhan, P.K. and Madhubala, R. (2008) Curr. Drug Targets, 9(11), 957-965.

[87] Reguera, R.M.; Díaz-González, R.; Pérez-Pertejo, Y. and Fouce, R.B. (2008) Curr. Drug Targets, 9(11), 966-978.

[88] Vanhamme, L. (2008) Curr. Drug Targets, 9(11), 979-996.

[89] Bajsa, J.; Duke, S.O. and Tekwani, B.L. (2008) Curr. Drug Targets, 9(11), 997-1012.

[90] Shi, W.; Ting, L.M.; Kicska, G.A.; Lewandowicz, A.; Tyler, P.C.; Evans, G.B.; Furneaux, R.H.; Kim, K.; Almo, S.C. and Schramm, V.L. (2004) J. Biol. Chem., 279(18), 18103-18106. 